Matgorzata Korzycka-Iwanow ${ }^{1}$

\title{
Ochrona własności rolniczej w nawiązaniu do koncepcji własności rolniczej Profesora Andrzeja Stelmachowskiego
}

„[...] ustawodawca konstytucyjny dostrzegt niebezpieczeństwo takich ograniczeń, które mogłyby wypaczyć treść prawa wtasności. Nie mogq bowiem doprowadzić do sytuacji, w której prawa wtaściciela dadzq się sprowadzić do nudum ius (, gotego prawa”) [...]”

Andrzej Stelmachowski

\section{Wprowadzenie}

Koncepcja własności rolniczej Profesora Andrzeja Stelmachowskiego, którą przedstawił po raz pierwszy pod koniec lat 60 -tych XX w., ${ }^{2}$ jest unikatową w doktrynie prawa polskiego ze względu na połączenie dwóch zakresów:

1) konstrukcji prawnorzeczowej, zawartej w kc.,

2) praw podmiotowych właścicieli gruntów, wywodzacych się z ustaw obowiązującego porządku prawnego i statuujących różnego rodzaju prawa i obowiązki.

Pamiętać trzeba, że tego rodzaju podejście zrywało z fikcją abstrakcyjnej kompetencji właściciela, który zgodnie z art. $140 \mathrm{kc}$. może (podkreśl. MKI), z wyłączeniem innych osób, w granicach określonych przez ustawy i zasady współżycia społecznego korzystać z rzeczy zgodnie ze społeczno-gospodarczym przeznaczeniem swego prawa - na rzecz właściciela, który prawo swoje wykonuje, i jest to zachowanie ze wszechmiar powszechne. Nie można pominąć elementu ustrojowego tej koncepcji, która nawiązuje do aktywnego, produkującego rolnika. Co prawda, do właścicieli indywidualnych gospodarstw rolnych ówcześnie obowiązująca Konstytucja odnosiła się w ujęciu klasowym, używając określenia „chłop” (określenie „rolnik", odwołujące się do zawodu, po raz pierwszy pojawiło się w PRL-u w ustawie z 1977 r. dotyczącej emerytur dla rolników), niemniej doznawał ochrony konstytu-

2 A. Stelmachowski, Wstęp do teorii prawa cywilnego, Warszawa 1969, s. 227. 
cyjnej. Polska Konstytucja stanowiła, że „Polska Rzeczpospolita Ludowa [...] otacza opieką indywidualne gospodarstwa rolne pracujących chłopów” (art. 15). Kodeks cywilny w art. 131 zawierał normę ogólną, iż przy tłumaczeniu i stosowaniu przepisów kodeksu cywilnego należy mieć na względzie opiekę, jaką Polska Rzeczpospolita Ludowa otacza indywidualne gospodarstwa rolne pracujących chłopów ${ }^{3}$. Towarzyszyły takiemu podejściu określone rozwiązania prawne, na mocy których ten, kto nie gospodarował prawidłowo (wg przyjętych wówczas kryteriów), mógł własność utracić - tym zaś, którzy ze względów obiektywnych obowiązkom tym nie mogli podołać (wiek, choroba), zaczęto przyznawać prawo do emerytury lub renty rolniczej.

Pracując pod kierunkiem Profesora Stelmachowskiego, byliśmy pod wrażeniem nowatorskiego spojrzenia na własność w rolnictwie - odrywającego się od utartych konstrukcji cywilistycznych i zuniformizowanej interpretacji art. $140 \mathrm{kc}$. Tworząca się w tym okresie szkoła prawa rolnego Profesora Stelmachowskiego zaczęła przynosić owoce w postaci prac Jego uczniów, które dotyczyły równiez problematyki własności w rolnictwie. Najszerzej własnością zajął się uczeń Profesora, Walerian Pańko w swojej wybitnej monografii: O prawie własności i jego współczesnych funkcjach ${ }^{4}$. W samym tytule pracy zaznaczone jest podejście funkcjonalne do prawa, które charakteryzowało szkołę Profesora Stelmachowskiego. W. Pańko analizował dylemat dotyczący pogodzenia prawa wyłączności właściciela z licznymi ograniczeniami tego prawa i stwierdził m.in., że ,,...] istotę prawa własności najprościej, ale i najpełniej wyraża idea domniemania kompetencji: domniemania leżącego po stronie właściciela, a odnoszącego się do ogółu zachowań względem określonej rzeczy (dobra). [...] Koncepcja domniemania generalnej kompetencji wydaje się być poglądem kompromisowym wobec dylematu: „monopol jednostkowy” albo „rozpisanie kompetencyjnej struktury własności ekonomicznej pomiędzy wszystkie podmioty w niej uczestniczące"s.

Rozczytywania konstrukcyjnej i faktycznej treści własności w odniesieniu do rolnictwa dokonywano w szczególności w ważnych w rozwoju naukowym pracach doktorskich i hablitacyjnych. Pisząc o faktycznej treści, mam również na myśli prowadzenie badań empirycznych, których prekursorem w powojennej nauce prawa prawa rolnego był Profesor Stelmachowski. ${ }^{6}$

Art. 131 kc. zawierał gwarancję własności i całkowitą ochronę indywidualnych gospodarstw rolnych, stanowiących trwały i równoprawny element społeczno-gospodarczego ustroju PRL.

Wyd. UŚ, Katowice $1984 \mathrm{r}$.

W. Pańko, O prawie własności i jego współczesnych funkcjach, Katowice 1984, s. 75-76.

Zob. np. E. Gniewek, J. Nadler, W. Pańko, A. Policiński, A. Stelmachowski, Przemiany własności ziemi w rolnictwie polskim, Wrocław 1974; A. Stelmachowski (red.), Wpływ instrumentów prawnych na przestrzenną strukturę rolnictwa”, Warszawa 1977; A. Stelmachowski, P. Czechowski (red.), „Ewolucja pozycji właściciela indywidualnego gospodarstwa rolnego w PRL, Warszawa 1989. 
Odnosząc się do własności w rolnictwie, trzeba pamiętać o całym, dość złożonym kontekście politycznym, ekonomicznym i społecznym tamtych czasów. Sytuacja polityczna i ekonomiczna uwarunkowana była sowietyzacją państwa, a mimo tego udało się zachować przez cały ten okres, jako zasadniczą formę produkcji w rolnictwie, indywidualne gospodarstwa rolne. Sytuację własnościową w polskim rolnictwie można bez wątpienia określić jako fenomen tamtych czasów wobec skolektywizowania rolnictwa w pozostałych państwach socjalistycznych.

Właścicielami w rolnictwie były nie tylko osoby fizyczne, istniała własność społeczna (w tym własność państwowa), obejmująca około 30\% ogółu gruntów. Wskaźniki planowe (zwłaszcza dyrektywne) krępowały bieżącą działalność jednostek państwowych. W istocie prawa państwowych osób prawnych bliższe były prawom użytkownika niż właściciela?

Stanisław Prutis ${ }^{8}$, który analizował własność państwową w okresie socjalizacji rolnictwa, wskazał na dominację statusu przedsiębiorstwa państwowego nad funkcją gospodarstwa rolnego, która wynikała $\mathrm{z}$ daleko idącego uniformizmu struktur i mechanizmów zarządzania sektorem gospodarki państwowej. Postawił tezę, iż uniformizm ten determinowały zarówno przesłanki natury ustrojowej, zaliczane do podstaw ówczesnego prawa gospodarczego, jak i zasady tego prawa. Wśród zasad tych szczególne znaczenie Stanisław Prutis przypisał zasadzie jednolitego funduszu własności państwowej jako strukturalnej przesłance uniformizacji oraz zasadzie planowości jako „fundamentu” uniwersalizacji funkcjonalnych instrumentów zarządzania.

Tego rodzaju „eksperyment legislacyjny” wprowadzony do praktyki działania prawa, tj. wtłaczający państwowe gospodarstwa rolne w sztywny gorset ograniczeń niedospasowanej struktury i centralistycznego systemu zarządzania stosowanego w przymyśle, nie mógł tym bardziej przynieść oczekiwanej efektywności w organizmach gospodarczych, w których ponadto konieczne było liczenie się ze szczególnymi cechami produkcji pozostającej w ścisłym związku z prawami natury i środowiskiem. W sposób oczywisty musiały mieć zastosowanie te zasady ekonomiczne, które uwzględniały określone ryzyko takiej produkcji. Istotne, że nie wszystkie przedsiębiorstwa państwowe miały podobny wynik ekonomiczny; w latach 80-tych, poprzedzających transformację, można było zauważyć pogłębiające się pod tym względem zróżnicowanie. Można było, niejako w podsumowaniu okresu socjalizacji w rolnictwie państwowym, u zarania III Rzeczypospolitej, wskazać wiele przedsiębiorstw zajmujących się postępem biologicznym (np. hodowlą twórczą w zakresie odmian roślin, hodowlą zarodową zwierząt), czy też wielokierun-

7 A. Stelmachowski, System..., s. 218

8 S. Prutis, Pozycja prawna państwowych przedsiębiorstw gospodarki rolnej (Ewolucja rozwiązań), Białystok 1987. 
kowo rozwijające produkcję (tzw. kombinaty rolnicze), które osiągały dobry wynik ekonomiczny nie tylko ze względu na dotacje państwowe, ale istotny wkład naukowy zespołów specjalistów. Nie bez znaczenia były umiejętności menedżerskie wykształconych w owym czasie na wyższych uczelniach osób, które zarzadzały tymi przedsiębiorstwami (zwłaszcza w późniejszych latach PRL-u), zapewniające właściwe funkcjonowanie tego czynnika produkcji, jakim jest organizacja. To dla wyżej wspomnianych przedsiębiorstw przewidziana była w ustawie o gospodarowaniu nieruchomościami rolnymi Skarbu Państwa z 1991 r. forma jednoosobowej spółki Skarbu Państwa. Przekształcenie państwowego przedsiębiorstwa gospodarki rolnej w taką spółkę umożliwiłoby niedokonywanie restrukturyzacji, a zatem nie byłoby możliwe i zasadne ich włączanie do Zasobu Własności Rolnej Skarbu Państwa. Forma jednoosobowej spółki Skarbu Państwa nie została, niestety, wykorzystana, przedsiębiorstwa przeszły biurokratyczną drogę wcielenia do Zasobu Własności Rolnej Skarbu Państwa, by w następstwie przyjąć formę spółki Agencji Nieruchomości Rolnych. To przykład oczywistego, jak na ironię, nieskorzystania z lekcji historii i pójście za stereotypem politycznym, postrzegającym wszystkie PGR-y jako twory $z$ gruntu nieudane i niebędące $w$ stanie funkcjonować na wolnym rynku. Na dobrą sprawę zastosowanie reguł gry rynkowej dla ogółu państwowych przedsiębiorstw gospodarki rolnej nie byłoby zbyt wielkim ryzykiem, a mogło przynieść dużo lepsze rezultaty. Potwierdzało się to z biegiem czasu, gdy gospodarowanie własnością państwową nie przebiegało właściwie, a po 20 latach od dokonania transformacji jest aż nadto widoczne'.

W latach 70-tych podjęłam w swojej pracy doktorskiej temat ochrony własności rolniczej ${ }^{10}$, który podsunął mi mój promotor - Profesor A. Stelmachowski. Przyjmując jako punkt wyjścia koncepcję własności rolniczej Profesora, postawiłam tezę, iż ochronę tego prawa należy dostrzegać przez pryzmat dobra chronionego i interesu, ze względu na który prawo ochrony tej udziela. Założeniem pracy było przedstawienie istoty zagadnienia ochrony w płaszczyźnie konfrontacji różnych dóbr i interesów, które konkurować będą z „,dobrem chronionym” w ramach własności rolniczej, tj. produkcją rolniczą. Oderwanie pojęcia własności rolniczej od prawa rolniczej własności gruntowej skutkowało równie szerokim potraktowaniem ochrony tego prawa. ryzacji i prywatyzacji rolnictwa państwowego, „Studia luridica Agraria” 2000, t. 1, s. 47 i n. Zob. również J. Nadler, Wady regulacji prawnej gopsodarowania nieruchomoscimai rolnymi Skarbu Panstwa, (w:) R. Budzinowski, A. Zieliński, Prawo rolne. Problemy teorii i praktyki, Poznań-Kluczbork 2001, s. 143 i n. 


\section{Własność rolnicza według Profesora Andrzeja Stelmachowskiego*}

Koncepcja własności rolniczej zaproponowana przez A. Stelmachowskiego polega na skojarzeniu oryginalnej konstrukcji prawa własności ze specyficznym przedmiotem tej własności, jakim jest gospodarstwo rolne. Według tej koncepcji własność rolnicza (wyodrębniana ze względu na przedmiot własności) jest kompleksem praw i obowiązków określających sytuację prawną podmiotu - właściciela gospodarstwa rolnego.

Koncepcja własności rolniczej stanowi istotny element dorobku doktrynalnego, leżącego u podstaw wyodrębnienia prawa rolnego jako nowej gałęzi prawa; może również stanowić - w płaszczyźnie dydaktycznej - oś porządkującą prezentację instytucji prawa rolnego. Warto więc przybliżyć tę koncepcję studiującym prawo rolne.

Trzon problematyki własnościowej jest oczywiście przedmiotem regulacji prawa cywilnego. Charakteryzując cechy ogólne prawa własności, jako szczególnej kategorii prawnej, A. Stelmachowski wskazuje, że prawo własności:

1) wyraża najszerszy zakres treściowy stosunku podmiotu do dóbr mu przypisanych;

2) przyznaje właścicielowi wyłączność (swoisty monopol) w odniesieniu do określonego przedmiotu;

3) charakteryzuje się specyficzną elastycznością ${ }^{12}$.

Cechy te dają się odnieść do wszelkich rodzajów własności, bez względu na to, co jest jej przedmiotem, w tym także do własności rolniczej.

Oryginalność podejścia A. Stelmachowskiego do własności polega na propozycji konstrukcji odmiennej od klasycznego, cywilistycznego modelu własności. Cywilistyczny model własności jest to model odziedziczony po prawie rzymskim (triada uprawnień właścicielskich), które kładło nacisk na prawo właściciela, absolutne wobec wszystkich innych. Właściciel miał prawa, nie miał natomiast wobec otoczenia żadnych obowiązków, przeciwnie, otoczenie miało obowiązek respektowania praw właściciela. Prawda, że dostrzeżono ograniczenia wynikające chociażby z praw sąsiedzkich, ale własność nie doznawała z tego powodu „erozji” w pojmowaniu go jako najszerszego prawo do rzeczy. Jest to konstrukcja uprawnień właściciela różniąca się od tej, jaką przyjęto dla zobowiązań, przy których mamy do czynienia z korelatem praw i obowiązków stron stosunku zobowiązaniowego.

Treść pkt 2 została wcześniej opublikowana w pracy zbiorowej „Prawo rolne”, pod. red. P. Czechowskiego, Warszawa 2011, s. 49-51, jako współautorstwo M. Korzyckiej-Iwanow oraz S. Prutisa.

12 A. Stelmachowski, Treść i wykonywanie prawa własności, (w:) System Prawa Prywatnego, t. 3, Prawo rzeczowe, pod red. T. Dybowskiego, 2. wyd., Warszawa 2007, s. 223. 
Już ponad 40 lat temu A. Stelmachowski zaproponował odmienną konstrukcję prawa własności, twierdząc, ,że błędem byłoby dziś ujmowanie własności li tylko jako prawa podmiotowego. Własność jest raczej kompleksem praw i obowiązków. [...] Kto wie, czy korelacja praw i obowiązków tak typowa dla praw obligacyjnych, nie powinna być także traktowana w zakresie praw bezwzględnych. Własność jest więc prawem skutecznym wobec ogółu, ale i ograniczonym ze względu na potrzeby ogółu"13.

Zastosowanie przez A. Stelmachowskiego ogólnej koncepcji prawa własności, jako kompleksu praw i obowiązków, do wyodrębnionej funkcjonalnie (ze względu na przedmiot regulacji) własności rolniczej było niezwykle trafne i przydatne dla obu dziedzin prawa - cywilnego i rolnego. $Z$ jednej strony koncepcja własności rolniczej wyjaśniała mechanizmy funkcjonowania prawa rolnego, z drugiej zaś - instytucje ze sfery własności rolniczej dostarczały argumentów podbudowujących ogólną koncepcję prawa własności.

Zdaniem Autora koncepcji odrębność własności rolniczej w płaszczyźnie funkcjonalnej istniała zawsze. Trudno bowiem negować specyficzny charakter produkcji rolnej, której istotnym elementem jest wykorzystanie ziemi jako niezbędnego czynnika produkcji. Produkcja rolnicza, z założenia, może być prowadzona tylko w ramach gospodarstwa rolnego jako zorganizowanej całości gospodarczej. Swoisty charakter gospodarstwa rolnego jako czynnej, zorganizowanej masy majątkowej powoduje, że te rozwiązania cywilistyczne, które odnoszą się do rzeczy, nie wystarczają dla określenia sytuacji prawnej zorganizowanej całości, jaką stanowi gospodarstwo rolne. I tu przydatna jest koncepcja własności rolniczej, która odnosi się do gospodarstwa rolnego jako swoistego mienia. Przedmiotem własności rolniczej jest gospodarstwo rolne ${ }^{14}$.

Tak rozumiana własność rolnicza uzyskuje pełny obraz dopiero wówczas, gdy weźmiemy pod uwagę nie tylko przepisy kodeksu cywilnego, ale i konglomerat przepisów różnej rangi kształtujących treść tej własności i sposób jej wykonywania. Co więcej, właśnie elementy pozacywilistyczne mają tu szczególne znaczenie. Chcąc dowiedzieć się, w jaki sposób może rolnik wykorzystać swą ziemię i inne składniki gospodarstwa rolnego, musimy sięgnąc do przepisów o ochronie gruntów rolnych, a także o ochronie środowiska, o planowaniu przestrzennym, a nawet do prawa budowlanego, gdy chodzi o wznoszenie budynków wchodzących w skład gospodarstwa. Aby ocenić poziom opłacalności w gospodarstwie, należy przestudio-

A. Stelmachowski, Wstęp do teorii prawa cywilnego, Warszawa 1969, s. 227 i 228; Zarys teorii prawa cywilnego, Warszawa 1998, s. 206. Zainteresowanych szerszym wyjaśnieniem koncepcji własności jako kompleksu praw i obowiązków odesłać należy do obszernych studiów A. Stelmachowskiego na temat treści i wykonywania prawa własności zamieszczonych (w:) System Prawa Prywatnego, op. cit., s. 213-314. machowski, Polskie prawo rolne na tle ustawodawstwa Unii Europejskiej, Warszawa 1999, s. 21-27; System Prawa Prywatnego, op. cit., s. 187-193. 
wać przepisy podatkowe, zasady kształtowania cen oraz liczne przepisy regulujące unijne branżowe rynki rolne. Na poziom dochodowości gospodarstwa rolnego rzutują płatności ze środków Unii Europejskiej. Co jednak charakterystyczne, rolnikowi przysługują płatności, jeżeli utrzymuje wszystkie grunty rolne zgodnie z normami tzw. dobrej kultury rolnej, przy zachowaniu wymogów ochrony środowiska. Mamy więc kompleks przepisów, które wpływają w sposób pośredni na możność korzystania przez rolnika z jego własności. Suma tych regulacji określa sytuację prawną rolnika.

W konkluzji rozważań A. Stelmachowski stwierdza: „z faktu, że własność rolnicza odnosi się do mienia, a więc do kompleksu praw i obowiązków, wynika, że własność rolnicza jest kompleksem praw i obowiązków. Właściciel ma w stosunku do innych nie tylko prawa, ale i obowiązki. Cechą charakterystyczną własności rolniczej jest, że wspomniane obowiązki odnoszą się nie tylko do określonych jednostek, ile wobec państwa reprezentującego interes społeczeństwa jako całości. W zamian za należyte wykonywanie własności rolniczej właściciel ma prawo liczyć na pomoc (ze strony państwa) przy wykonywaniu swego prawa własności"15.

\section{Ochrona własności rolniczej}

Ochrona własności rolniczej stanowi kontynuację zasadniczej myśli Autora koncepcji, obejmuje zatem nie tylko ściśle rzeczowy charakter prawa własności rolniczej, ale mienie w postaci gospodarstwa rolnego. Istotny jest zatem zarówno przedmiot, jak i zakres (intensywność) ochrony ${ }^{16}$. Dla ochrony poszczególnych składników stosuje się prawo cywilne, odnoszące się do rzeczy, a dla ochrony gospodarstwa rolnego niezbędne będzie ograniczenie prawa rozporządzania jego składnikami.

Ochrona własności rolniczej przejawia się w zakresie szeroko pojętej sukcesji gospodarstw rolnych, tj. dokonywanej za życia (umowa z następcą, renta strukturalna), jak i mortis causa (w szczególności w obrębie zasad działu spadku uregulowanych w kc.). Kierunek ochrony własności rolniczej w zakresie zmiany pokolenia to dążność do zapewnienia zdolności produkcyjnej gospodarstwa. Podobnie gdy chodzi o zniesienie współwłasności gospodarstwa rolnego; przyjęte kryterium podziału to przede wszystkim zgodność z zasadami prawidłowej gospodarki rolnej.

Rozważając przedmiot ochrony, należy zwrócić uwagę na dwa elementy: 1) ze względu na jakie dobro w poszczególnych okresach historycznych udzielano prawu własności ochrony i równocześnie, 2) czyj interes miano na uwa- 
dze, udzielając ochrony, innymi słowy, będzie to pytanie o funkcję prawa własności ${ }^{17}$.

Najbardziej złożony problem ochrony własności rolniczej związany z prawem rzeczowym dotyczy korzystania z rzeczy (art. 140 kc.), na co już wyżej zwrócono uwagę. Istotny wpływ na wykonywanie prawa mają tutaj normy z zakresu ochrony środowiska, ochrony gruntów rolnych, planowania przestrzennego, ale też prawa budowlanego, energetycznego, przepisy o opodatkowaniu działów specjalnych, ulgach podatkowych $\mathrm{i}$ in.

Własność rolnicza i jej ochrona mają swoje „przełożenie” na przepisy konstytucyjne $^{18}$. Zdaniem Andrzeja Stelmachowskiego ustawodawca konstytucyjny dostrzegł niebezpieczeństwo takich ograniczeń, które mogłyby wypaczyć treść prawa własności. Nie mogą bowiem doprowadzić do sytuacji, w której prawa właściciela dadzą się sprowadzić do nudum ius (,gołego prawa") i w związku z tym twierdzi, że „,najtrudniejszym jest problem ochrony własności rolnej w zakresie tego jej atrybutu, który tradycyjnie określamy mianem korzystania z rzeczy (art. 140 kc.). Chodzi tu bowiem o konglomerat norm prawnych, które regulują inne materie, ale w sposób niekiedy pośredni wpływają na prawo korzystania z rzeczy"19.

Kwestię tę można współcześnie odnieść np. do kontrowersji związanych z uprawami roślin genetycznie zmodyfikowanych w sytuacji, gdy ich uprawa w otwartym środowisku ma bez wątpienia zasadniczy - ograniczający wpływ na prawa własności właścicieli gruntów ziemskich położonych w sąsiedztwie tych, na których taka uprawa jest prowadzona.

W konkluzji pojawia się punkt najbardziej istotny. „Otóż inaczej przedstawia się ochrona własności rolniczej jako mienia zorganizowanego dla celów produkcyjnych, a inaczej ochrona składników gospodarstwa rolnego. Dla ochrony poszczególnych składników stosuje się reguły i prawidła prawa cywilnego odnoszące się do rzeczy. Natomiast na prawo ochrony gospodarstwa rolnego rozumianego w sensie art. $55^{3} \mathrm{kc}$. nie możemy patrzeć wyłącznie przez pryzmat prawa własności jego poszczególnych składników. Co więcej, może okazać się, że dla ochrony gospodarstwa rolnego niezbędne będzie ograniczenie prawa rozporządzania jego składnikami. [...] Ogólnie można stwierdzić, że dopiero po zapoznaniu się z całym systemem instrumentów prawnych, przy pomocy których państwo reguluje zarówno produkcję rolną, jak i rynek rolny, można wydać osąd, w jakim stopniu chronione jest pra-

17 M. Korzycka, Ochrona własności rolniczej, Warszawa 1979, s. 14. 18 W sprawie P 11/98 Trybunał Konstytucyjny stwierdził, że „mówiąc o tym, iż własność nie jest ius infinitum [...] nie ne, ponieważ wyznaczaja granice prawa własności. Przepisy ustawowe nie moga bowiem niweczyć podstawowych uprawnień składających się na treść prawa własności, takich jak możliwość korzystania, pobierania pożytków lub pośredniego eksploatowania przedmiotu własności." ustrojowe, w szczególności, s. 192. 
wo do korzystania z własności rolniczej. Stąd też doszło do ukształtowania się wyspecjalizowanej gałęzi prawoznawstwa, jaką jest prawo rolne"20.

\section{Ochrona własności rolniczej wobec środków prawnych Wspólnej Polityki Rolnej Unii Europejskiej; spojrzenie porównawcze z okresem socjalizacji rolnictwa}

Jedną z wyrazistych cech twórczości naukowej Profesora Stelmachowskiego było niezwykle trafne stawiane diagnozy danej sytuacji prawnej, określenie rzeczywistych funkcji prawa i przyszłych kierunków jego rozwoju, pozbawione iluzji ideologicznych i przywiązań do schematów doktryny prawniczej. Jako autorce pracy dotyczacej ochrony własności rolniczej napisanej pod kierunkiem Profesora w okresie socjalizacji rolnictwa, pokusą jest zderzenie wówczas stawianych tez w celu ich weryfikacji ze współczesnymi uwarunkowaniami.

Warto byłoby zatem przypomnieć pojęcie interesu chronionego w obrębie własności rolniczej z okresu państwa socjalistycznego i odczytać w odniesieniu do obowiązujących regulacji w obszarze rolnictwa. Zastrzegam, że chodzi jedynie o wskazanie podstawowych pojęć i rozwiązań prawnych.

W systemie socjalistycznym rola państwa była bardzo rozbudowana i dotyczyła zarówno kontroli rynku rolnego, jak i poszczególnych czynników produkcji, tj. ziemi, kapitału, pracy i organizacji. Regulacja rynku rolnego i poszczególnych, wymienionych wyżej czynników produkcji realizowana była przez państwo socjalistyczne przy wykorzystaniu rygorystycznych środków centralnie planowanej gospodarki.

Obecnie w Polsce sytuacja w tym zakresie, tj. zakresie ingerencji prawa w działalność rolniczą stała się zaskakująco zbliżona do tej z okresu socjalizacji rolnictwa. Zaznaczam, że refleksje na temat podobieństw odnoszę do sfery prawnej, a zatem treści regulacji, środków i instytucji kształtowanych przez prawo. Nie wypowiadam się na tematy ekonomiczne, a zatem również na temat efektów ekonomicznych, stosowanych w przeszłej epoce i współcześnie środków prawnych, nie mając po temu przygotowania zawodowego, tym samym narzędzi badawczych. Środki prawne stosowane w okresie socjalizacji rolnictwa były inspirowane czy wręcz kopiowane $\mathrm{z}$ radzieckiego systemu zarządzania gospodarką, co jest faktem obiektywnym. Wobec przesunięcia po 1989 r. naszych interesów politycznych i ekonomicznych na zachód i integrację z Unią Europejską przyjęto inny, unijny model zarządzania rolnictwem. Kontrola władzy publicznej dotyczy głównie sfery regulacji rynku rolnego, ale równiez strukur na obszarach wiejskich i realizowana jest za pomocą nie tylko oddziaływujących, ale silnie ingerujących środków prawnych Unii Europejskiej w ramach Wspólnej Polityki Rolnej. Zakres tematyczny tego opraco- 
wania nie jest nastawiony na szczegółowe przedstawianie funkcjonowania norm prawa unijnego w zakresie WPR i innych polityk UE, stąd też ograniczam się jedynie do zasygnalizowania zagadnień związanych z ochroną własności rolniczej.

Na wstepie tych rozważań należy zaznaczyć, że prawo do własności stanowi prawo podstawowe w ramach Karty Praw Podstawowych. Ma to ten skutek, że nie tylko winno być respektowane przez instytucje UE oraz państwa członkowskie, ale też chronione. Ze względu na ścisłą integrację gospodarczą, swobodę przedsiębiorczości nie można wyłączyć prawa własności z orbity zainteresowania prawa UE. Proces integracji ekonomicznej zakreśla granice, w jakich państwa człaonkowskie mogą swobodnie kształtować swój własnościowy porządek prawny, ponieważ nie pozwala on na naruszanie zasad prawa $\mathrm{UE}^{21}$.

Rolnictwo traktowane jest w prawie pierwotnym i wtórnym UE jako wyjątkowy sektor, który wyłączony jest po części $z$ reguł wolnorynkowych. Na mocy art. 42 TFUE (dawny art. 36 TWE) ogólne reguły konkurencji mogą być zastosowane do produkcji rolnej i handlu produktami rolnymi jedynie w zakresie ustalonym przez Radę i po przeprowadzeniu odpowiedniej procedury legislacyjnej. Po latach obowiązywania tych reguł można stwierdzić, że wyłączenie rolnictwa spod regulacji wolnorynkowych spowodowało zwiększenie dochodów rolników, a jednocześnie zmniejszenie dysproporcji w stosunku do dochodów $\mathrm{z}$ innych dziedzin gospodarki. Proces ten odbył się jednak kosztem wyższych cen płaconych za produkty rolne wyprodukowane w Unii i jest obecnie przedmiotem ostrej krytyki ${ }^{22}$.

Zmiany wprowadzone w Lizbonie (art. 43 TFUE) przewidują, że decyzje w zakresie rolnictwa będą podejmowane nie tylko przez Radę, jak to miało miejsce do tej pory, ale przy udziale Parlamentu Europejskiego, w drodze ,zwykłej procedury prawodawczej”. Traktat Lizboński wyłącza więc Wspólną Politykę Rolną z tradycyjnych negocjacji międzypaństwowych i przenosi na poziom ważnych europejskich decyzji politycznych. Rzeczywisty wynik tego zabiegu jest jednak trudny do określenia, ponieważ model zarysowany w Traktacie z Lizbony wzmacnia w wyraźny sposób pozycję Komisji Europejskiej (,,rządu UE”), której znaczenie - nie tylko zresztą w zakresie materii rolnej, ale ogólnie w zakresie jej kompetencji unijnych - znacząco rośnie.

Nie można, zdaniem moim, nie zauważyć daleko idącego podobieństwa co do charakteru prawnego paternalizmu państwa socjalistycznego i Unii Europejskiej. Ów paternalizm wyraża się w instrumentach prawa unijnego, sterujących rolnictwem, w tym rynkiem rolnym na poziomie całej Unii i poszczególnych państw i W. Piskorza, Implikacje reform Wspólnej Polityki Rolnej Unii Europejskiej, Warszawa, UKIE, 2002, w szczególności s. 31 in. 
członkowskich. Ochrona własności przejawia sie zatem w sposób pośredni jako ochrona dochodów rolniczych ${ }^{23}$. Jest to w pełnej korespondencji z zasadniczym celem UE utrzymania dochodów rolniczych na niezmienionym poziomie przy jednoczesnym obniżeniu produkcji i wyeliminowaniu zagrożeń dla środowiska naturalnego.

W Polsce Ludowej środki oddziaływania na rolnictwo i rynek były niezwykle szeroko stosowane i przenikały niemalże każdą sferę działalności rolniczej. Prawo zawierało m.in.: określony system ustalania cen, zasad finansowania produkcji rolnej, opodatkowania działalności rolniczej gospodarstw indywidualnych i uspołecznionych (państwowych i spółdzielczych) ${ }^{24}$, obowiązki właścicieli gruntów rolnych i sankcje z tytułu niewykonywania tych obowiązków (przepisy o gospodarstwach opuszczonych, o przymusowym wykupie nieruchomości wchodzących w skład gospodarstw rolnych, o przejmowaniu gospodarstw na rzecz państwa w zamian za emeryture lub rentę, o uregulowaniu własności gospodarstw rolnych, o wywłaszczaniu nieruchomości). Szczegółowo regulowano wykonywanie własności rolniczej i organizację produkcji rolniczej oraz umowy o produkcję i usługi rolnicze ${ }^{25}$. Istotne, że cechą wspólną wspomnianych umów, podobnie jak pod rządami obecnie obowiązującego prawa, był splot metody cywilistycznej i administracyjnoprawnej; ta ostatnia dotyczyła przede wszystkim organizacji poddanej systemowi administracyjnemu (nakazowo-zakazowemu) ówczesnego państwa.

Nie roszcząc sobie prawa do szerokiego analizowania stosowanych wówczas i teraz instrumentów prawnych, chcę wskazać na wspólny mianownik obu modeli zarządzania rolnictwem, sprowadzający się do dereminanty w postaci silnego wpływu na korzystanie z własności i jej ochronę.

Prawo unijne wyznacza w Traktacie dla całej Unii Europejskiej cele Wspólnej Polityki Rolnej, z których bodaj najbardziej istotny to wspomniana wyżej ochrona dochodów rolników. Zmieniają się natomiast na przestrzeni lat (w chwili obecnej ok. 60-ciu) środki oddziaływania tej polityki. Co godne podkreślenia, cele Wspólnej Polityki Rolnej ujęte w Traktacie (obecnie art. 39 TFUE) pozostały niezmienione od czasów Traktatu Rzymskiego w żadnym punkcie. Gdy chodzi o rolnictwo polskie, to w okresie kilkunastoletniego okresu stowarzyszenia, a od 2004 członkostwa w UE poddane zostało oddziaływaniu Wspólnej Polityki Rolnej, wraz z jej nie-

Tak. A. Stelmachowski, (w:) P. Czechowski, M. Korzycka-lwanow, S. Prutis, A. Stelmachowski, Polskie prawo rolne na tle prawa Unii Europejskiej, Warszawa 1994, s. 14 i n.

„Poprzez regulację cen, kredytów itp. tworzy się ukierunkowany <<nacisk ekonomiczny>>, stwarzający okreslone warunki rynkowe dla chłopów. Istniejące tu unormowania prawne zmierzają do takiego ograniczenia żywiołowości działania sił ekonomicznych na rynku rolnym indywidualnego rolnictwa, aby je można było wykorzystać dla realizacji zadań wynikających z planów dotyczących produkcji”, tak (w:) A. Stelmachowski, B. Zdziennicki, Prawo rolne, Warszawa 1980, s. 65 i n. 
zmienionymi celami, ale za to zmieniającymi się stosunkowo często instrumentami.

Chociaż środki prawne stosowane w PRL były inne od stosowanych przez EWG/UE, ale ich zasięg zbliżony jest do zarysowanych wyżej środków prawnych unijnej polityki rolnej. Dość wskazać występujące na przestrzeni lat takie instrumenty WPR, jak: ceny rolne ( $w$ rozbiciu na ceny docelowe, ceny kierunkowe, ceny interwencyjne, ceny podstawowe, ceny progu, ceny śluzy, ceny wycofania z rynku), zryczałtowane płatności bezpośrednie (SPS), subwencje produkcyjne, zakupy interwencyjne, cła i inne środki pochodne ochrony rynków wewnętrznych, licencje importowo-eksportowe, certyfikaty, dopłaty eksportowe i opłaty, kwoty produkcyjne. Są to również instytucje wyłączania gruntów rolnych z produkcji (odłogowanie, zalesianie, przeznaczanie na cele agrośrodowiskowe). Istnieje też, na podstawie przepisów pochodzących z lat 2000, bogata instrumencja strukturalnego rozwoju obszarów wiejskich. Właściciel gospodarstwa jest przy tym z reguły producentem pierwotnym lańcucha żywnościowego, obejmującego wszystkie etapy produkcji, przetwarzania i dystrybucji ${ }^{26}$, na którego końcu stoi konsument. Ponadto właściciel, z racji przynależnego mu najszerszego, w tradycji prawa kontynentalnego, prawa do rzeczy (tu: nieruchomości rolnej) - prawo to może najpełniej realizować.

Nie sposób nie odnotować na kanwie prowadzonych rozważań, iż pojawiają się w najnowszej literaturze gorzkie refleksje, iż polskie władze scedowały na Unię Europejską prowadzenie polityki rolnej tak dalece, że nie wykorzystują możliwości aktywnego oddziaływania na strukturę agrarną nawet na tych obszarach, w których można to czynić w drodze ustawodawstwa krajowego ${ }^{27}$.

Nowe standardy produkcji w UE, skupiające się na jakości produktów rolnych i żywnościowych, przyniosły w efekcie wprowadzenie nowych wymogów prawa unijnego w zakresie cross-compliance. System ten oznacza wiele surowych norm dotyczących ochrony środowiska, dobrostanu zwierząt i bezpieczeństwa żywności. Nowy stan prawny otwiera pytania dotyczące kierunków i środków ochrony własności rolniczej. Odpowiedzi należy poszukiwać w płaszczyźnie zetknięcia się właściciela gospodarstwa rolnego z nałożonymi na niego uprawnieniami i obowiązkami, wykraczającymi juz dzisiaj wyraźnie poza samą produkcję, rolną roślinną i zwierzęcą. Funkcje właściciela w rolnictwie sięgnęły zatem obszaru środowiska naturalnego czlowieka i jakości produktu pierwotnego, określanej certyfikowanymi systemami (np. system rolnictwa ekologicznego, system dobrostanu zwierząt, sy178/2002 w sprawie ustanawiające ogólne zasady i wymagania prawa żywnościowego, powołujące Europejski Urząd ds. Bezpieczeństwa Żywności oraz ustanawiające procedury w zakresie bezpieczeństwa żywności. 
stem produktów rolnych i żywnościowych w zakresie nazw pochodzenia i oznaczeń geograficznych).

Nie można abstrahować od faktu, że wszystkie wymienione wyżej środki kształtowały i kształtują pozycję ekonomiczną (głównie dochody) producentów i konsumentów na rynku Unii Europejskiej oraz reguły handlu z krajami trzecimi. Mając powyższe na uwadze, można zaproponować odpowiedź na pytanie dotyczące interesu, ze względu na który właściciel w rolnictwie doznaje ochrony prawa.

Interes (funkcję), ze względu na który własność rolnicza doznaje ochrony w obecnie obowiązującym w Polsce porządku prawnym, można określić jako wypełnianie przez właścicieli gospodarstw rolnych prawa Unii Europejskiej w zakresie korzystania z mienia rolniczego.

Ochrona własności rolniczej związana jest z aktywnością właściciela, który jest producentem. W chwili obecnej przede wszystkim prawo Unii Europejskiej w obrębie Wspólnej Polityki Rolnej decyduje o korzystaniu z własności rolniczej. Wraz ze zmianami zachodzącymi w prawie regulującym produkcję rolniczą w każdym zakresie, tj. ziemi, kapitału, pracy i organizacji - zmianie ulegają środki prawne udzielanej przez prawo ochrony. Trzeba zdawać sobie sprawę, że podobnie jak w okresie socjalizacji rolnictwa, środki prawne mają swoje źródło w ukształtowanym poza naszym krajem modelu zarządzania rolnictwem, który w Polsce został wprowadzony. 


\section{Protection of agricultural property in reference to the concept of agricultural property by professor Andrzej Stelmachowski}

Key words: agricultural property, singular flexibility, function of property, agricultural holding

The concept of agricultural property as proposed by A.Stelmachowski relies on the association of the original construction of property law with its specific object, i.e. the farmstead. According to this concept, agricultural property (specified in respect of the matter of ownership) is a complex of laws and obligations describing the legal standing of the subject - farm owner. The concept of agricultural property is an important element of the doctrinal accomplishment underlying the distinguishing of agricultural law as a new branch of legislation; it may also form - on the didactic level - an axis to organise the presentation of agricultural law institutions.

Core ownership issues are obviously regulated by civil law. To describe the general features of property law, as a particular legal category, A.Stelmachowski indicates that property law

1) possesses the most comprehensive content as regards the relationship of the subject to the property attributed to him;

2) awards the owner exclusive right (a certain monopoly) as regards a specified object;

3 ) is characterized by a singular flexibility.

All of these features can be referred to various kinds of ownership, regardless of its subject, including agricultural property.

The originality of A. Stelmachowski's approach to ownership arises from a proposed construction which is different to the classic, civil law model of ownership. This model has been inherited from Roman law (triad of ownership), which stressed the absolute rights of the owner. The owner had rights but no obligations towards the others, on the contrary, they are obligated to respect the rights of the owner.

The protection of agricultural property is a continuation of the essential idea of the concept Author, and thus encompasses not only the substantive nature of agricultural law but property, that is a farmstead, itself. Important are both the subject and the scope (intensity) of protection. To protect the individual components civil regulations on property are applied, and to protect the farm, it is necessary to restrict the right to dispose of its components at will. When considering the subject of protection, one should take note of two elements: 
Ochrona własności rolniczej w nawiazaniu do koncepcji własności rolniczej...

1) what goods in various historical periods effected protection of the property law, and equally

2) whose interests were taken into account when awarding the protection, in other words, this will be a query regarding the function of property law.

The interest (function) which brought about protection of agricultural property in the legal order currently in place in Poland could be described as execution by farmstead proprietors of European Union legislation on the use of agricultural holdings.

Similarly as in the period of socialist economy in agriculture, the legal measures are rooted in a model of farming administration developed outside Poland, and introduced here. 